\title{
Awareness about Mouth Cancer in Biotechnology Students
}

\author{
Muhammad Imran Qadir * and Azra Yasmeen \\ Institute of Molecular Biology \& Biotechnology, Bahauddin Zakariya University, Pakistan \\ *Corresponding author: Muhammad Imran Qadir, Institute of Molecular biology \& Biotechnology, Bahauddin Zakariya Univesity, Multan, Pakistan
}

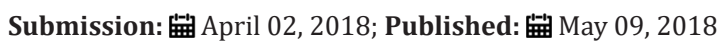

\begin{abstract}
Uncontrolled division of cells causes cancer. Mouth cancer is caused by many factors and the major causes of mouth cancer are Tobacco use, heavy alcohol use and infection by HPV (Human Papillomavirus). Another factor of mouth cancer is UV-light which can cause lip cancer. Some factors are genetic factors. If genetic instability occurs in Keratinocytes then cancer is developed. The main reason of mouth cancer is Tobacco, cigarettes. Questioners about awareness of mouth cancer were solved by biotechnology students. Total 38 students performed to solve this questioner. The responses of these questions were analyzed. Total 32 females and 6 males solved the questioner. And by studying the questioner it was concluded that $73.68 \%$ students agreed that mouth cancer is a viral disease and $34.21 \%$ agreed that mouth cancer is genetic disease, $68.4 \%$ students agreed that mouth cancer transfer from parents to offspring's and 31.5\% students agreed that this disease is curable. So few students were fully aware few were not aware about mouth cancer. And the objective of this study is to aware biotechnology students about mouth cancer in Bahauddin Zakariya University Multan.
\end{abstract}

Keywords: Mouth cancer; Tobacco; Papiloma virus; Awareness; Treatment; Cavity

\section{Introduction}

Cluster of abnormal cells form cancer. Mouth cancer occurs due to continuous loss of skin, mucous membrane or oral mucosa. Mouth cancer includes cancer of larynx, throat, lips, nose and salivary glands. Causes of mouth cancer are Tobacco use, heavy alcohol use and infection by HPV (Human Papillomavirus) [1]. Cancer is a preventable disease. Its occurrence in peoples over 50 years is most common [2]. If genetic instability occurs in Keratinocytes then cancer is developed. Mostly Tongue, floor of mouth cavity and lower lips are affected, and then surgery, chemotherapy and radiotherapy

are used for treatment of mouth cancer [3]. The basic purpose of this study was to determine the awareness of biotechnology students about mouth cancer.

\section{Methods}

A questioner is prepared and solved from different students of biotechnology and views of different students were collected, and inclusion criteria was students of postgraduate and exclusion criteria was students was not of BS level (Table 1).

Table 1: Questionnaire to evaluate awareness about etiology of

\begin{tabular}{|c|c|c|}
\hline Mouth cancer & Yes & No \\
\hline Mouth cancer is a & & \\
\hline Viral disease & & \\
\hline Bacterial disease & & \\
\hline
\end{tabular}

\begin{tabular}{|c|l|l|}
\hline Fungal disease & \multicolumn{2}{|l|}{} \\
\hline Genetic disease & & \\
\hline Metabolic disease & & \\
\hline Ever suffered from Mouth cancer \\
\hline You & & \\
\hline Your family & & \\
\hline Your relative & & \\
\hline Your neighbor & & \\
\hline Your friend & & \\
\hline Mouth cancer is transmitted by \\
\hline Contacts or blood transfusion & \\
\hline From parents to offspring & \\
\hline Mouth cancer may be treated by & \\
\hline Medicines & & \\
\hline Surgery & & \\
\hline Do not worry, it is easily curable & & \\
\hline
\end{tabular}

\section{Results and Discussion}

Awareness about etiology of mouth cancer in biotechnology students showed that in Table $133.3 \%$ of the male students agreed that mouth cancer is a viral disease and $66.6 \%$ male students agreed that mouth cancer is not a viral disease and $81.25 \%$ female students agreed that mouth cancer is a viral disease and $18.75 \%$ of female students disagreed that mouth cancer is a viral disease totally out 
of 38 students $73.68 \%$ of the students agreed that mouth cancer is a viral disease and $26.31 \%$ students agreed that mouth cancer is not a viral disease. And according to questioner 33.3\% male and $43.75 \%$ of female agreed that mouth cancer is a bacterial disease and $66.6 \%$ male and $56.25 \%$ female students agreed with that mouth cancer is not a bacterial disease. And 33.3\% male and $37.5 \%$ female students agreed that mouth cancer is a fungal disease, and $66.6 \%$ male and $59.37 \%$ female students agreed with that mouth cancer is not a fungal disease. And $16.6 \%$ male and $37.5 \%$ female students agreed that mouth cancer is a genetic disease and $83.3 \%$ male and $62.5 \%$ female students agreed with that mouth cancer is not a genetic disease and $33.3 \%$ male and $28.1 \%$ female students agreed with that mouth cancer is a metabolic disease and $66.6 \%$ male and $62.5 \%$ female students agreed that mouth cancer is not a metabolic disease.

When studying the awareness of these students in relation to them about mouth cancer, in their family, relatives and in their friends then table 2 showed that $0 \%$ male and $0 \%$ female suffered from disease and 100\% male and female both not suffered from that moth cancer and both male and female showed that their family never suffered from that disease and showed that their relatives never suffered from that disease and $16.67 \%$ male and $3.12 \%$ students showed that their neighbors suffered from that mouth cancer and $83.3 \%$ male and $96.8 \%$ female students showed that their neighbors not suffered from mouth cancer, and all male and female students showed that their friends never suffered from that mouth cancer

When knowing about the knowledge of biotechnology students about awareness of mouth cancer in table $30 \%$ male and $25 \%$ female students agreed that mouth cancer can be transmitted by blood transfusion and $100 \%$ male and $75 \%$ female students agreed that mouth cancer can be transmitted by blood transfusion and $16.67 \%$ male and $34.4 \%$ female students agreed that mouth cancer transfer from parents to offspring's and $83.3 \%$ male and $65.6 \%$ female students agreed with that mouth cancer cannot transfer from parents to offspring's.

The awareness of biotechnology students about treatment of mouth cancer showed that in table $483.3 \%$ male and $93.7 \%$ female students agreed that mouth cancer can be treated by medicines and $16.67 \%$ male and $6.25 \%$ female students agreed that mouth cancer cannot be treated by medicines and $83.3 \%$ male and $84.3 \%$ female students agreed with that mouth cancer can be treated by surgery and $16.67 \%$ male and $15.6 \%$ female students agreed with that mouth cancer cannot be treated by mouth cancer and $50 \%$ male and $28.1 \%$ female students agreed with that mouth cancer can be cured easily and $50 \%$ male and $72.8 \%$ female students agreed with that mouth cancer cannot be easily cured (Table 2-5).

Table 2: Awareness about etiology of Mouth cancer: Views of Postgraduate Biology Students.

\begin{tabular}{|c|c|c|c|c|c|c|}
\hline \multirow{2}{*}{ Questions } & \multicolumn{2}{|c|}{ Male } & \multicolumn{2}{c|}{ Female } & \multicolumn{2}{c|}{ Total } \\
\cline { 2 - 7 } & Yes & No & Yes & No & Yes & $26.31 \%$ \\
\hline Viral disease & $33.30 \%$ & $66.60 \%$ & $81.25 \%$ & $18.75 \%$ & $53.68 \%$ & $57.80 \%$ \\
\hline Bacterial disease & $33.30 \%$ & $66.60 \%$ & $43.75 \%$ & $56.25 \%$ & $52.10 \%$ & $36.80 \%$ \\
\hline Fungal disease & $33.30 \%$ & $66.60 \%$ & $37.50 \%$ & $59.37 \%$ & $34.21 \%$ & $65.70 \%$ \\
\hline Genetic disease & $16.60 \%$ & $83.30 \%$ & $37.50 \%$ & $62.50 \%$ & $34.21 \%$ & $63.10 \%$ \\
\hline Metabolic disease & $33.30 \%$ & $66.60 \%$ & $28.10 \%$ & $62.50 \%$ & $2 \%$ & \\
\hline
\end{tabular}

Table 3: Awareness about etiology of Mouth cancer: Views of Postgraduate Biology Students.

\begin{tabular}{|c|c|c|c|c|c|c|}
\hline \multirow{2}{*}{ Questions } & \multicolumn{2}{|c|}{ Male } & \multicolumn{2}{|c|}{ Female } & \multicolumn{2}{|c|}{ Total } \\
\hline & Yes & No & Yes & No & Yes & No \\
\hline \multicolumn{7}{|c|}{ Ever suffered from Mouth cancer } \\
\hline You & $0 \%$ & $100 \%$ & $0 \%$ & $100 \%$ & $0 \%$ & $100 \%$ \\
\hline Your family & $0 \%$ & $100 \%$ & $0 \%$ & $100 \%$ & $0 \%$ & $100 \%$ \\
\hline Your relative & $0 \%$ & $100 \%$ & $0 \%$ & $100 \%$ & $0 \%$ & $100 \%$ \\
\hline Your neighbor & $16.67 \%$ & $83.30 \%$ & $3.12 \%$ & $96.80 \%$ & $5.26 \%$ & $94.70 \%$ \\
\hline Your friend & $0 \%$ & $100 \%$ & $0 \%$ & $100 \%$ & $0 \%$ & $100 \%$ \\
\hline
\end{tabular}

Table 4: Awareness about etiology of Mouth cancer: Views of Postgraduate Biology Students

\begin{tabular}{|c|c|c|c|c|c|c|}
\hline \multirow{2}{*}{ Questions } & \multicolumn{2}{|c|}{ Male } & \multicolumn{2}{c|}{ Female } & Notal \\
\cline { 2 - 7 } & Yes & No & Yes & No & Nos \\
\hline \multicolumn{1}{|c|}{$\begin{array}{c}\text { Mouth cancer is transmitted by } \\
\text { transfusion }\end{array}$} & $0 \%$ & $100 \%$ & $25 \%$ & $75 \%$ & $21 \%$ & $78.90 \%$ \\
\hline From parents to offspring & $16.67 \%$ & $83.30 \%$ & $34.30 \%$ & $65.60 \%$ & $31.50 \%$ & $68.40 \%$ \\
\hline
\end{tabular}


Table 5: Awareness about etiology of Mouth cancer: Views of Postgraduate Biology Students.

\begin{tabular}{|c|c|c|c|c|c|c|}
\hline \multirow{2}{*}{ Questions } & Male & & Female & & Total & \\
\hline & Yes & No & Yes & No & Yes & No \\
\hline \multicolumn{7}{|c|}{ Mouth cancer may be treated by } \\
\hline Medicines & $83.30 \%$ & $16.67 \%$ & $93.70 \%$ & $6.25 \%$ & $92 \%$ & $7.89 \%$ \\
\hline Surgery & $83.30 \%$ & $16.67 \%$ & $84.30 \%$ & $15.60 \%$ & $84.20 \%$ & $15.70 \%$ \\
\hline $\begin{array}{l}\text { Do not worry, it is } \\
\text { easily curable }\end{array}$ & $50 \%$ & $50 \%$ & $28.10 \%$ & $72.80 \%$ & $31.50 \%$ & $68.40 \%$ \\
\hline
\end{tabular}

Same type of work about awareness of mouth cancer was conducted in different countries like Saudi Arabia, Oman in Dentists [4].

\section{Conclusion}

It is concluded from this study that biotechnology students about awareness of mouth cancer that few students were aware few were not aware about mouth cancer.

\section{References}

1. Chaturvedi AK, Engels EA, Anderson WF, Gillison ML (2008) Incidence trends for human papillomavirus-related and-unrelated oral squamous cell carcinomas in the United States. Journal of clinical oncology 26(4): 612-619.
2. Silverman S (2001) Demographics and occurrence of oral and pharyngeal cancers: the outcomes, the trends, the challenge. J Am Dent Assoc 132(suppl): 7S-11S.

3. Azimi S, Ghorbani Z, Ghasemi E, Tennant M, Kruger E (2018) Disparities in Oral Cancer Awareness: a Population Survey in Tehran, Iran. J Cancer Educ: 1-7.

4. Joseph BK, Sundaram DB, Ellepola AN (2015) Assessing oral cancer knowledge among undergraduate dental students in Kuwait University. J Cancer Educ 30(3): 415-420.
Creative Commons Attribution 4.0 International License

For possible submissions Click Here
Submit Article

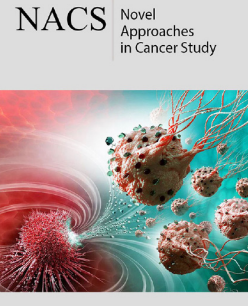

\section{Novel Approaches in Cancer Study}

Benefits of Publishing with us

- High-level peer review and editorial services

- Freely accessible online immediately upon publication

- Authors retain the copyright to their work

- Licensing it under a Creative Commons license

- Visibility through different online platforms 